\title{
Environmental Injustice in Pakistan: Impacts of Upstream Dams on Indus Delta and its Inhabitants
}

\author{
Abdul Hadi \\ Ph. D Student. Ankara University, Faculty of Letteres, Department of Sociology, Sihhiye, 06110, Ankara, Turkey \\ hadijarwar@gmail.com
}

\section{Doi:10.5901/ajis.2015.v4n1s2p11}

\begin{abstract}
The aim of this study is to focus on the adverse impacts of upstream dams on Indus delta and its inhabitants. The large dams and barrages, besides their global economic significance, have become the focus of strong discussion on account of their frequently severe social and environmental impacts. These negative impacts do not impinge on all people but people who are poor powerless and belong to marginalized ethnic minorities. Since the inception of Pakistan, Punjabi a dominant ethnic group in Pakistan controls armed forces and key political institution and make all decision without considering the interests of Sindh. The construction of dams raises serious environmental justice concerns, with economic benefits for upper riparian Punjab and social and environmental costs for Sindh. The construction activities on Indus River were accomplished largely without getting consensus from Sindh violating the agreement between Sindh and Punjab. Excessive water diversion by Punjab has resulted in the economic, social and ecological problems in Sindh. Deltaic communities of Sindh who draw their livelihood directly from communal access to land, water, forests, coastal mangroves, and other ecosystems are being the hardest hit by the construction of large dams. Sindhi people, especially deltaic people are subjected to environmental injustice due to their subordinate status in Pakistan.
\end{abstract}

Keywords: Internal-colonialism, Environmental Injustice, Impacts of Dams, Indus Delta, Sindh.

\section{Introduction}

The greatest edifice of human ingenuity large dams are used as powerful symbols of modernization, national prestige, and of human supremacy over nature (McCullay, 2001). The most prominent purpose of building large dams is the Generation of hydropower. Other basic purposes of large dams include the seasonal or annual storage of water for human consumption, agrarian and industrial production and for the reduction of flood peaks. Besides their global economic significance, large dams have become the focus of strong discussion on account of their frequently severe social and environmental impacts. These negative impacts do not impinge on all people but people who are poor powerless and belong to marginalized ethnic minorities.

Patrick McCully (2001) argues that the domination of rivers clearly indicates the link between the control of nature and the control of people. Since the creation of Pakistan, Many large dams, barrages and canals are built in Pakistan. Sindh's civil society organizations and politicians of all dispensation are in concurrence that large dams and barrages in Pakistan are built to give dominant ethnic group Punjabi the ability to direct water for their own benefits, depriving the Sindh and in particular the deltaic people of Sindh. Thus, Sindhis are subjected to environmental injustice.

\section{Historical Background}

Pakistan is not one country composed of only one Nation but is a conglomeration of socio-cultural different nationalities. The 'ethnic minorities' that basically comprise the smaller nations of Pakistan never supported the creation of Pakistan. But British imperialists decided to divide up India for strategic reasons and purposely set out to create a new state called Pakistan against the wishes of Sindh and other minority ethnic groups. The Pakistani state was created by putting together ethnic groups that had never before been united in the same polity before British. Sindhi, Baluch and Pashtuns resisted Punjabi invasions for centuries. After the construction of Pakistan, Sindhi, Baluch, and Pashtuns feel that they are trapped in a political set up which is run by dominant province Punjab since Punjab controls armed forces and key political institutions (Harrison, 2009). Historically Sindh remain a sovereign country. Since the creation of Pakistan, Sindhi lost their political autonomy which has eventually threatened their distinct culture and language (UNPO, 2012). 
Sindh is also deprived of its due share of Indus waters, due to the construction of large dams, and barrages and canals located in and benefitting the Punjab where the political power centers of the military and state also reside (Rahman, 2009). The genesis of the water dispute historically lies between the British annexed states of Sindh and Punjab, much before they became provinces of Pakistan. It all started when British colonialist rewarded agriculture lands to the Punjabi soldiers and officers due to their loyal services to British masters in suppressing the indigenous rebellion movement against the British colonialists in 1857 (Rahman, 2009, Talpur, 2001). In order to irrigate these lands, British colonialists started massive water projects in Sindh without the consent of lower riparian Sindh whose rights were perceived to be already established under international and subcontinental laws, which safeguard the rights of the lower riparian. In spite of their obvious imperialist bias in favor of the Punjab, the British did not view the grave injustice being done to Sindh like a spectator. When Punjab planned to build new projects on Indus river system, Sindh objected that the projects has potential threats to its agriculture and economy. Both provinces were under colonial administration with some indigenous representation and each side negotiated robustly defending its rights. These negotiation documents contain the agreement that was reached finally in 1945 known as the Sindh-Punjab Water Agreement which granted 75\% share of waters to Sindh and 25\% to Punjab, as Punjab had access to four other rivers (Rahman, 2009).

The blatant violation of this accord started since the creation of Pakistan. Before the creation of Pakistan, there was only one barrage built on the river Indus. Since the creation of Pakistan, all of the 19 barrages, 43 canal systems, three major storage dams and 12 link canals that have been built in Pakistan after partition, have been in Punjab. The share of Sindh from Indus water has been drastically reduced. This has brought great benefits to the agriculture of Punjab at the expense of Sindh. In contrast to 94 million-acre feet of water that reached Indus delta before partition. Now the Indus River dries up hundreds of miles before reaching the delta and 1. 2 million Sindhi farmers and fishermen have lost their livelihood and out-migrated since the partition. The construction activities on Indus River were accomplished largely without getting consensus from Sindh violating the agreement between Sindh and Punjab. All of these construction activities other than the two additional barrages in Sindh mostly benefits Punjab. Most of the land brought under cultivation due to barrages in Sindh was distributed among non-Sindhis (Memon, 2002).

Excessive water diversion by Punjab has resulted in the economic, social and ecological problems in Sindh. Sindh is being deprived of its rightful share and getting less share (IUCN, 2007). Sindhis feel that Punjab is robbing its water and denying of its historic rights to Indus water endorsed by Punjab itself in 1945 agreement. The crisis arising from shortage has compelled many political groups to protest as they claim that their rightful share of water is being stolen (Rinaudo, 2001). Thus, since the creation of Pakistan, Sindhi people are subjected to environmental Injustice. Environmental injustice takes place when some people or communities bear environmental burdens disproportionately, like those of hazardous waste dumps, or has unequal access to environmental good, like clean air, or has less opportunity to participate in environmental decision-making process (Shrader-Frechette, 2002).

The literature that addresses issues of environmental injustice indicate that race tends to be more important than class in most cases, although both are sometimes significant determinants of environmental injustice. However, In this case, Environmental injustice with deltaic communities in Pakistan can be explained with the help of "Internal Colonialism Theoretical" Perspective.

\section{The Internal Colonialism Theoretical Model}

Colonialism is a process in which more powerful nations exploit other nations and show their economic and sociopolitical dominancy over them. In contrast, internal colonialism is a condition in which both the dominant group and subordinate groups co- exist as natives of the same society (Adeola, 2000). All around the world, the minorities and indigenous communities pay the prices of social and environmental harm.

Historically Sindh remains a sovereign country. Since the creation of Pakistan, Sindhi lost their political autonomy which has eventually threatened their distinct culture and language (UNPO, 2012). The prevalence of internal colonialism has been noted in this study wherein a dominant ethnic group Punjabi in control of a government systematically exploits resources of Sindhi people. This is an environmental injustice with Sindhis resulting from their subordinate and colonial status in Pakistan. Thus, Sindhis are facing environmental injustice due to prevalence of internal-colonialism.

Punjabi being a dominant ethnic group abuses its absolute power to exploit the resources of periphery (Sindh) to develop the core (Punjab). Deltaic people who draw their livelihood directly from communal access to land, water, forests, coastal mangroves, and other ecosystems are being the hardest hit by the construction of large dams. The construction of dams raises serious environmental justice concerns, with economic benefits for upper riparian Punjab and social and environmental costs for Sindh. Most of the Sindhi people depend upon the water of Indus River. Shortage of 
it not only create environmental problem but also social problems. Construction of dams in Punjab have made their fertile lands barren, and disrupted their family and social life.

\section{Impacts of Upstream Dams on Indus Delta and Its Inhabitants}

\subsection{Impacts on Delta and its Ecosystem}

Indus Delta which is located in Sindh is totally dependent upon water of Indus River. It covers a large part of the province of Sindh, occupying about 3 million hectares. It is about $240 \mathrm{~km}$ in length along the axis of the river and $220 \mathrm{~km}$ at its widest. The formation of Indus delta has become due to high Indus river discharge. However, Excessive water diversion at upstream has drastically reduced the quantity of water and silt from reaching the Indus Delta. Consequently, Indus delta is being rapidly transgressed (Memon, 2005).

The ecosystem of delta area is in under stress from the encroachment of sea and increasing salinity. Sea water has intruded in many areas along the coast pressurizing the livelihood of fishing and farming communities. According to WWF Pakistan Director Ghulam Akber (2009) 2 million acres of fertile delta have been eroded due to inadequate release of water in the Indus downstream of Kotri (The News, 2009).

When Indus River discharge into the sea, it sustains the mangrove forests. Mangroves are essential component of the coastal system. The World Bank (2005) reports that mangroves of Indus Delta were spread in 345,000 hectares, but now these mangroves cover only 160,000 to 200,000 hectares. Even the remaining area is being degraded. Mangroves have been decimated mainly by low Indus flows below Kotri, according to the Environmental Concerns Report (GoP Study II 2005) of the international group set up by the Government of Pakistan. In a detailed study of the Indus delta, Haq (1999) points out that the active delta has shrunk to less than one tenth of its original size (from 2,600 km2 to $260 \mathrm{~km} 2$ ) (Khan, 2005).

\subsection{Socio-economic impacts on Deltaic region}

Before the construction of upstream dams, Lands of this region were fertile, rice and other crops were cultivated. People used to tender animals, everyone had 50 or 100 animals (livestock). Fish was in abundance. People were prosperous and lived happy life. However, the construction of upstream dams severely impacted the lives of deltaic people. The livelihoods of millions of fisher-folk, of agriculture and of livestock-rearing communities as well as the naturally rich ecosystem of the region has threatened with the degradation of Indus delta (Action Aid Pakistan, 2005). The joint Government of Sindh-World Bank report on socioeconomic conditions in the coastal districts of Badin and Thatta points out that in the past, people of coastal region used to generate income through multiple income sources. Fishing was a main source of livelihood along with crop and livestock farming. The decline in flow forced communities to shift their livelihood to fisheries (WB 2005). For many, fishing has become a livelihood of the last resort, but the yield, too, is decreasing (Ghazanfar, 2009).

\subsection{Impact on Agriculture}

The income generating crops, such as red rice crops, Orchards of banana, papaya and guava are almost destructed. Government of Sindh Conducted a survey which indicated that just within three districts of this region over 486,000 hectares land were either eroded or lost due to sea intrusion and quarter million people were dislocated. Recently, it is estimated that 567,000 hectares of the land lost to the sea (Memon, 2004). Loss of fertile lands has created economic down turn and forced people to migrate. Hundreds of villages in both Badin and Thatta districts have been migrated to other areas (Kazi, 2004).

\subsection{Fish Depletion}

The depletion of fish is on the increase. The catch of a number of fish species has drastically reduced. There is a considerable decline in Migratory fish species, such as Pallo and Barramundi (SAP, 2001). Pallo accounted for 70\% of the total catch in the past. But now it barely constitutes 15 percent of the total catch. 


\subsection{Livestock}

In the past, due to its fertility including vast tracts of green pastures, Katcha and mangrove forests, the Delta region of Sindh had remained ideal for livestock grazing. The Delta agriculture community had been rearing large numbers of livestock, including cattle, camels, goats, sheep, etc. As such, the Deltaic region was famous for its milk, butter oil or ghee and other associated products of livestock. With the decline in fresh water flow due to upstream dams, fertility of this area included grasses and pastures withered and lost. With the shortage of pastures and grasses, livestock become physically weak and were attacked by various diseases. The majority of the livestock died while the villagers, due to growing poverty, sold the remaining livestock (Memon, 2005).

Ensuing Poverty: The impact of resource degradation in Sindh and the Deltaic region has emerged in the form of poverty. The people of rural Sindh and especially the Indus Delta have been hit hard. Due to the scarcity of water and resulting economic downturn, people are finding it very hard to make the ends meet. Unemployment, poverty, crime rate, and other social problems are all on the rise. Over two thirds of population is under the poverty line. Poverty has harmed the cultural values. For instance, Traditional Sindhi hospitality is on a rapid decline. Economic pressures have engendered psychological problems. Suicide rates are on increase, especially among young and women (Memon, 2004).

\subsection{Forced Migration}

The decline in Indus flow at delta has resulted in sea intrusion and resource degradation. Both sea intrusion and resource degradation forced people to migrate to other areas of Sindh. It is estimated that 90,000 people have become displaced and 120 villages uprooted (Brohi, 2004).

\subsection{Availability of Water for Drinking}

The reduction in Indus River flows has created a crisis-like situation with the shortage of drinking water. The drinking water supplies have dwindled and degraded in quality. Thus local people are forced to drink brackish and contaminated water which has caused an increase of 200 percent of water borne diseases jut in the last few decades. The report of National Conservation Strategy (NCS) indicates that about $40 \%$ deaths occur due to water-borne diseases. Worse sufferers are the women, children and aged-people (Zaigham, 2006).

\section{Conclusion}

Since the creation of Pakistan, the dominant ethnic group Punjabi violating the Sindh-Punjab water accord signed by both parties in 1945 constructed many large dams and barrages on Indus River. Being a demographically and politically dominant, Punjabi makes all decision without taking account of the interests of Sindh. These dams, barrages and canals are located in and benefitting the Punjab. The construction of dams raises serious environmental justice concerns, with economic benefits for upper riparian Punjab and social and environmental costs for Sindh. Excessive water diversion by Punjab has resulted in the economic, social and ecological problems in Sindh. Deltaic people of Sindh who draw their livelihood directly from communal access to land, water, forests, coastal mangroves, and other ecosystems are being the hardest hit by water diversion at upstream. Diseases are prevalent due to unhygienic drinking water. Everyone is struggling for their survival and make their ends meet. Thousand acres of agriculture land has so far been devoured by sea and thousands of people have forcedly migrated to other cities. Sindhi people, especially deltaic people are subjected to environmental injustice. This is all due to their colonial and periphery status in Pakistan.

\section{References}

Action Aid Pakistan. (2005). Degradation of Indus Delta: lives of 2 million poor are at risk," Action Aid report, http: //www.actionaid pakistan. org, February 8.

Adeola, F. O. (2000). Cross-National Environmental Injustice and Human Rights Issues, a Review of Evidence in the Developing World.

Brohi, S. (2004). Socio-economic Impact of Reduced Indus Flow on Indus Delta and Its Local Communities, National Seminar, University Of Sindh, Jamshoro, January15 - 16.

Ghazanfar, M. (2009). The Environmental Case of Sindh. Lahore Journal of Policy Studies 3 (1).

GoP. (2005). Study of water escapages downstream of the Kotri Barrage to address environmental concerns (Studyll). Final main report. Kotri Barrage Study-II Consultants group, Islamabad: Government of Pakistan, Ministry of Water and Power and Federal Flood 
Commission of Pakistan

Harrison, S. S. (2009). Pakistan: The State of the Union. Special Report. Center for International Policy.

IUCN. (2007). Sindh Strategy for Sustainable Development, Planning and Development department Government of Pakistan. http: //cmsdata. iucn. org/downloads/sssd. pdf.

Kazi, A. M. (2004). Overview of Water Resources in Pakistan, National Seminar, University of Sindh, Jamshoro, Pakistan, January15 16, 2004.

Khan, S. R. (2005). Envrionmental and other contested aspects of the Kalabagh dam project. SDPI Research and News Bulletin 12 (5).

Magsi, H. , And Atif, S. (2012). Water Management, Impacts and Conflicts: Case of Indus water distribution in Sindh, Pakistan.

McCully Patrick, (2001): Silenced Rivers-The ecology and politics of large dams: Enlarged and Updated edition, Zed Books Ltd.

Memon, A. A. (2002). An overview of the history and impacts of the water issue in Pakistan. In: Proceedings of the International Conference on Sindh, the water issue and the future of Pakistan. The Wolrd Sindhi Institute. . Washigton DC.

Memon, A. A. (2004). Evaluation of Impacts on the Lower Indus River Basin Due to Upstream Water Storage and Diversion. WWER Congress, Salt Lake City, Utah, June 27 - July 1, p 9.

Memon, A. A. (2005). Devastation of the Indus River Delta. Proceedings, World Water \& Environmental Resources Congress 2005, American Society of Civil Engineers, Environmental and Water Resources Institute, Anchorage, Alaska. (Note - Expanded version).

Rahman, H. (2009). Ethnic Tensions and the Future of Pakistan: The Case of Sindh. In S. S. Harrison (2009). Pakistan: The State of the Union. Special Report. Center for International Policy (67-73).

Rinaudo, J. D. (2001). Corruption and water allocation: the case of public irrigation in Pakistan, Water Policy, 4: 405-422.

SAP. (2001). Water Crisis in Pakistan (News Clippings, Reports, Articles)," A South Asia Partnership Report, May 4, 2001.

Shrader-Frechette. (2002). Environmental Justice: Creating Equality, reclaiming Democracy. Oxford University Press.

Sornarajah. (1981). Internal Colonialism and Humanitarian Intervention M. , Ga. , J. , Int'l \& Comp. , L. [Vol. 11: 1.

Talpur, M. A. M. (2001). Water shortage in Sindh: Causes and consequences, Sangat (SANA) Spring 2001, 17 (1): 9 -1.

The News. (2009). Deforestation, water pollution major threat to Sindh. The News (English newspaper). http: //www. thenews. com. pk/TodaysPrintDetail. aspx?ID $=181703 \& C a t=4 \& d t=6 / 7 / 2009$.

UNPO. (2012). Report of The General Secretary to the 11th UNPO General Assembly May 2010 - November 2012. UNPO International Secretariat. Unrepresented Nations and Peoples Organization.

UNPO. (2013). UNPO Celebrates World Environment Day. Unrepresented Nations and Peoples Organization.

WB. (2005). Socio-economic study and proposal for livelihood improvement: Badin and Thatta Districts, Sindh, Pakistan. Agriculture and Rural Sector unit South Asia Region. Washington: World Bank.

Zaigham, N. A. (2006). Impact Of Controled Environmental Flow \& Earthquake Activities On Indus Delta Causes Irreversible Poverty. 
